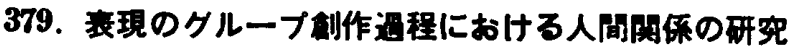
英城大学教育学部○助川 貞子・熱田 粶 英城大学教育学部附属小学校 松丸 令子・木村 順子

日立市立多賀中学校 神 長

I. 研究目的 昨年度小学校5年生対象に行いました “表現のタルーブ創作過程における人間関係の研究”で より望ましいグルーブ構成の仕方を追求してまいりまし たので，本年は昨年と同一方法で，中学 2 年女子を対象 に実験を行い，発達段階に扣いてどのようなことがみら れるかを追求してみよらとした。

\section{II. 研究社面}

対象一荻大附中 100 名中 48 名 多賀中学252名中 48名抽出

蒘 造

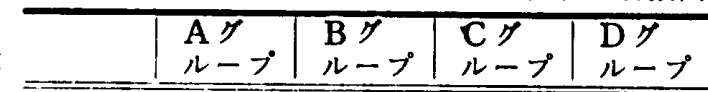

知能|中|⿴囗十年 性格中中虫中出中中 表現中中中中 中中 上 リーダー互選指名互選指名互選指名互選指名

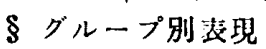

・課題 “夕立ち”

-45分ずつら回

-1回・5回8ミリ撮影, 行動観察, 相互評価, 動機ず け，内省テスト等

III. 結果と考察 考察 1.グループの㹡張性と作品成 績との関係，グループの構成が作品成績にどのような影
響を与えるかを㭘討するために，各グルーブの㹡張性や 作品成績の 5 回目を, 高いすのから順位化しその相関を スピアマンの係数によつて算出しましたところ, 中学に 於ける実験の結果, 附属中は $\gamma_{\mathrm{s}}=0.394$, 多賀中 $\gamma \mathrm{s}=0.019$ と云う低い值で，特にグループの拡張性と作品成䢂との 相関はみられなかつた。

考察 2.リーダーの社会的地位と作品成績との関俰, リーダーの社会的地位によつて，どのよ5に影敏される かをスピフマンの俰数によると, 附属中 $r s=0.212$, 多 賀中 $r s=-0.365$ で相関関係はみられない.

考察 3. 作品成績が及ぼす要因分析, 作品成績阙す る要因として，グルーブ構成とリーダーの発生の要因分 析をした結果，多賀中のリーダー発生に， $12.5 \%$ の有意 性がみられた。附属中のDタルーフ，多賀中の A・D ループを除いては，互選よりも指名リーダーの方が作品 成績がすぐれている。

まとめ 以上のことを総括的にまとめてみると，小学 校と中学校と共通している点は作品成絓が及ぼす要因に 打いて，同し傾向がみられたが，クループの㹡張性と作 品成績との関保及びリーダーの社会的地位と作品成紸の 関係に怙いて，一部共通の点すみられたが，むしろ逆の 場合もみられた。これは小学校 5 年生は始めて自主的に クルーブ活動が可能になる年令でこの時期は心理学的に も集団はまとまり易く行動は模倣的であるのに対し，中 学生になると特に個性化が強くみられ発達段階において 急激な心身の変化によるあらわれとみるできであろ5。 他のいろいろな要因がこの結果の原因をきたすすのと思 われるので更に細かく追求することを今後の研究とした い.

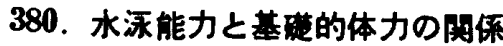

$$
\begin{aligned}
& \text { 親和女子大学 } \bigcirc \text { 阪 上 光 代 } \\
& \text { 天理大学岸梄夫 }
\end{aligned}
$$

水泳の初心者指導の際，技能の習得に著しく困難を感 じる者が少なくない：これらの者に対する指導上の問題 点を把握する為に，水泳の能力と，水泳の技能習得に必 要と思われる基礎的作力との関保を明らかにしよ5と試 みた.

研究方法 対象訬小学校 4,5,6 年生男女 230 名で，各 学年男女別に上位と，下位より $25 \%$ つつ抽出し，それぞ れを上位群, 下位群とした。調査, 湘定項目は泳力と, 表に示した12項目である。

考萐とまとめ一般運動能力では，走脁，ボール投 げ，男子の斜孯垂に有意差があり全身の支配力之，伸屈 の笳力が泳力に影響している. 筋力では, 腹筋と有意差 がある. 最初に選択する泳法に，伏し浮きの勢から入 る者が多く，もともと腹筋の強い者が，この姿勢での挍 能習得が容易であることを示している．筋協応性では， 両種目共に有意差があり，正確に早く，手と足の動作を リズミカルに働かせることの必要性が誌められる。柔軟 性では，前屈に有意羙があり，後屈に差が認められない のは，前述の筋力と同様のことが考光られ，泳法の選択 に関保が深いことが教察される．足首に打いては，伸曲
に盖が認められ，上，下の柔軟性が泳力に関俰している ことを示している.

水泳能力つ少る者は，ある特定の能力が劣つている為 に，水泳の技能習得が困難とい之ず，一般運動能力，筋 力，筋協机性，柔軟性などの基磷的な体力が全般的に劣 る事が恋められた．従つて一部の能力を高めるのではな く，全般的な能力の向上と共に，水泳指導の機会をより 多くすることが，水泳技能の習得を容易にするものと考 える.

\section{表基磁的体力の泳力别比蛟}

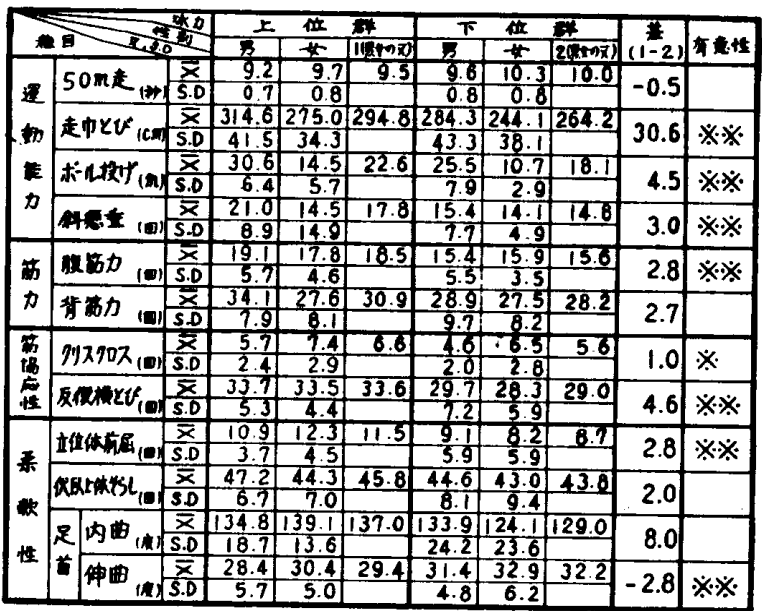

